\title{
Tsunami source area of the 2011 off the Pacific coast of Tohoku Earthquake determined from tsunami arrival times at offshore observation stations
}

\author{
Yutaka Hayashi, Hiroaki Tsushima, Kenji Hirata, Kazuhiro Kimura, and Kenji Maeda \\ Seismology and Volcanology Research Division, Meteorological Research Institute, 1-1 Nagamine, Tsukuba, Ibaraki 305-0052, Japan
}

(Received April 7, 2011; Revised June 16, 2011; Accepted June 22, 2011; Online published September 27, 2011)

\begin{abstract}
The source area of the tsunami generated by the 2011 off the Pacific coast of Tohoku Earthquake estimated from tsunami arrival times recorded at offshore wave gauges, GPS buoys, cabled ocean-bottom pressure gauges, and tsunami buoys is about $500-\mathrm{km}$ long with a maximum width of approximately $200 \mathrm{~km}$. The 2011 tsunami source area includes several segments of previous recurring large earthquakes. However, the northern and southern parts of the large Japan Trench segment were not included in the source area. The southern off-Boso-Peninsula part of the Japan Trench segment has the potential to generate a large tsunami earthquake in near future.
\end{abstract}

Key words: DART buoy, Japan, multi-segment earthquake, ocean-bottom pressure gauge, RTK-GPS buoy, seismic gap, tsunami back-propagation.

\section{Introduction}

The 2011 off the Pacific coast of Tohoku Earthquake occurred at 05:46:23 on 11 March, 2011 (UTC). The epicenter of the earthquake $\left(38.104^{\circ} \mathrm{N}, 142.861^{\circ} \mathrm{E}\right)$ was southeast of Sendai City and its moment magnitude $\left(M_{\mathrm{w}}\right)$ was 9.0 , according to the Japan Meteorological Agency (JMA), which means that it was probably the largest earthquake in the recorded history of Japan. The tsunami that accompanied the earthquake was detected at various offshore observation stations, including coastal wave gauges (Nagai, 1998; Nagai et al., 2005), real-time kinematic global positioning system (RTK-GPS) buoys (Kato et al., 2005), cabled deep ocean-bottom pressure gauges (OBPG) (e.g. Fujisawa et al., 1986; Hirata et al., 2002), and Deep-ocean Assessment and Reporting of Tsunami (DART) buoys (González et al., 2005). Coastal wave gauges and RTK-GPS buoys are part of Japan's Nationwide Ocean Wave Information Network for Ports and Harbours (NOWPHAS).

Several series of large recurring earthquakes with source areas on the plate boundary of the subduction zone under the Japan Trench have been identified by the Earthquake Research Committee (ERC, 2005). Determining which earthquake segments have ruptured during individual earthquakes is of crucial importance in the evaluation of the potential for subduction-related seismic activity along the Japan Trench in the near future.

We determined the areal extent of the source area of the tsunami caused by the 2011 off the Pacific coast of Tohoku Earthquake by using tsunami arrival times recorded at offshore observation stations. We then determined which of the segments of recurring earthquakes in the area were

Copyright (c) The Society of Geomagnetism and Earth, Planetary and Space Sciences (SGEPSS); The Seismological Society of Japan; The Volcanological Society of Japan; The Geodetic Society of Japan; The Japanese Society for Planetary Sciences; TERRAPUB.

doi:10.5047/eps.2011.06.042 within the tsunami source area.

\section{Data}

Waveform data showing sea-level heights obtained at various offshore observation stations off Tohoku and neighboring districts were collected. Although damage caused either by the tsunami or by ground motions eventually stopped the transmission and recording of data from all the observation stations along the Sanriku Coast, most of these data were successfully recovered afterwards by operating institutes. This data was processed as follows. A low-pass finite impulse response (LP-FIR) filter with a cutoff period of 2 min was applied to sea-level height data from OBPGs and DARTs to eliminate wind waves; we used equivalent products (filtered long-wave components) distributed by Ministry of Land, Infrastructure, Transport and Tourism (MLIT) instead of filtering raw sea-level height data from coastal wave gauges and GPS buoys (Fig. 1). The tsunami arrival times and the subsequent arrivals of initial troughs, primary crests, and local crests were then read manually from the processed waveform data. Initial troughs were read only when they preceded the primary crest.

A total of 21 tsunami arrival times were recorded. Six of these were from coastal wave gauges, 6 were from RTKGPS buoys, 6 were from OBPGs, and 3 were from tsunami buoys (one Russian tsunami buoy and 2 DART buoys). 18 primary crests were also recorded (Table 1).

\section{Method}

To find the edge of the tsunami source area, Huygen's principle was applied to back-propagate the tsunami from each observation station. For these calculations we used Geoware tsunami travel-time software (TTT v. 3.0) and bathymetric data at one-minute intervals (ETOPO1; Amante and Eakins, 2009). The phase velocity of tsunami propagation was assumed to be equal to the square root of gravity multiplied by bathymetry. A tentative tsunami 
Table 1. Tsunami waveform data recorded during the tsunami of the 2011 off the Pacific coast of Tohoku Earthquake.

\begin{tabular}{|c|c|c|c|c|c|c|c|}
\hline \multicolumn{3}{|c|}{$\begin{array}{l}\text { Instrument type, number, location and } \\
\text { bathymetry }(\mathrm{m})\end{array}$} & \multicolumn{2}{|c|}{$\begin{array}{l}\text { Initial wave } \\
\text { arrival time } \\
\end{array}$} & \multicolumn{3}{|c|}{ Arrival time for each phase ${ }^{2}$} \\
\hline \multicolumn{3}{|c|}{ Coastal wave gauges ${ }^{a}$} & & & & & \\
\hline WS613 & Kushiro Port & 50.0 & $15: 27(-2)$ & $\mathrm{U}$ & - & - & $15: 42$ \\
\hline WS602 & Tomakomai Port & 50.7 & $15: 34(-2.5)$ & D & $15: 47$ & - & $16: 04$ \\
\hline WS202 & Mutsu-Ogawara Port & 43.8 & $15: 21(-2.5)$ & $\mathrm{D}$ & $15: 29$ & - & $15: 43$ \\
\hline WS203 & Hachinohe Port & 27.7 & $15: 17(-2)$ & $\mathrm{D}$ & $15: 38$ & $15: 43$ & $\mathrm{x}$ \\
\hline WS219 & Kuji Port & 49.5 & $15: 02(-2)$ & $\mathrm{D}$ & $15: 21$ & - & $\mathrm{x}$ \\
\hline WS205 & Sendai New Port & 21.3 & $14: 54(-1)$ & $\mathrm{D}$ & $15: 33$ & - & $\mathrm{x}$ \\
\hline \multicolumn{3}{|c|}{$\overline{\text { RTK-GPS buoys }^{a}}$} & & & & & \\
\hline GPS807 & Off Northern Iwate & 125 & $14: 56(-2)$ & $\mathrm{D}$ & $15: 11$ & $15: 15$ & $15: 19$ \\
\hline GPS804 & Off Central Iwate & 200 & $14: 47$ & $\mathrm{D}$ & 14:59 & 15:07 & 15:12 \\
\hline GPS802 & Off Southern Iwate & 204 & $14: 48$ & $\mathrm{D}$ & $14: 57$ & - & $15: 12$ \\
\hline GPS803 & Off Northern Miyagi & 160 & $14: 47$ & $\mathrm{D}$ & $14: 56$ & - & $15: 14$ \\
\hline GPS801 & Off Central Miyagi & 144 & $14: 47$ & $\mathrm{D}$ & $\mathrm{x}$ & - & $15: 17$ \\
\hline GPS806 & Off Fukushima & 137 & $14: 51(-1)$ & $\mathrm{U}$ & - & $15: 04$ & $15: 16$ \\
\hline \multicolumn{3}{|l|}{ Cabled OBPGs } & & & & & \\
\hline KPG1 & Off Tokachi $1^{\mathrm{b}}$ & 2218 & $15: 02(-2)$ & $\mathrm{U}$ & - & 15:05 & $15: 12$ \\
\hline KPG2 & Off Tokachi $2^{b}$ & 2210 & $15: 08(-2)$ & $\mathrm{U}$ & - & 15:11 & $15: 24$ \\
\hline TM1 & Off Kamaishi $1^{\mathrm{c}}$ & 1618 & $14: 47$ & $\mathrm{U}$ & - & $14: 58$ & 15:01 \\
\hline TM2 & Off Kamaishi $2^{c}$ & 1013 & $14: 47$ & $\mathrm{D}$ & $14: 52$ & - & 15:05 \\
\hline $\mathrm{BOSO} 2$ & Off Boso $2^{d}$ & 2090 & $15: 05(-2)$ & $\mathrm{U}$ & - & - & $15: 21$ \\
\hline $\mathrm{BOSO} 3$ & Off Boso $3^{d}$ & 1898 & $15: 08(-2)$ & $\mathrm{U}$ & - & - & $15: 24$ \\
\hline \multicolumn{3}{|c|}{ Tsunami buoy ${ }^{\mathrm{e}}$} & & & & & \\
\hline DART21401 & SE off Etorofu Island & $5.3 \times 10^{3}$ & $15: 44(-2)$ & $\mathrm{U}$ & - & - & $15: 53$ \\
\hline \multicolumn{3}{|l|}{ DART buoys ${ }^{\mathrm{f}}$} & & & & & \\
\hline DART21418 & NE off Tokyo & 5685 & $15: 13(-0.5)$ & $\mathrm{U}$ & - & - & 15:19 \\
\hline DART21413 & SE off Tokyo & 5822 & $16: 02(-1.5)$ & $\mathrm{U}$ & - & - & 16:07 \\
\hline
\end{tabular}

a-f. Sources of waveform data were (a) Port and Harbour Bureau, Ministry of Land, Infrastructure, Transport and Tourism (MLIT), (b) Japan Agency for Marine-Earth Science and Technology (JAMSTEC), (c) Earthquake Research Institute (ERI) at Tokyo University, (d) Japan Meteorological Agency (JMA), (e) Russian Far Eastern Regional Hydrometeorological Research Institute (RFERHRI), (f) National Oceanic and Atmospheric Administration (NOAA).

1. Bold numbers indicate almost identical arrival times for seismic and tsunami waves. Numbers in parentheses are corrections (minutes) to allow for rupture velocity. The direction of the initial deflection of the tsunami waveform is indicated by $U$ (up) and $D$ (down).

2. The cells containing " $x$ " indicate no data and cells containing "-" indicate no corresponding phase in the tsunami waveform.

source area was then estimated as an area surrounded by the back-propagation lines.

In general, the travel time of a tsunami from its origin to a particular observation station is approximately equal to the time difference between the occurrence of the main shock and the tsunami arrival. However, for very large earthquakes the difference between the time of the main shock and the generation of the tsunami is not negligible (Seno and Hirata, 2007). Therefore, in this study, we modified the tsunami travel times by $1 \mathrm{~min}$ corresponding to a distance of $120 \mathrm{~km}$ from the epicenter to the contact point of the back-propagation line and the tentatively-determined tsunami source area (Table 1). This correction is to account for typical differences between the time of the main shock and the generation of the tsunami; this is almost equivalent to assuming an averaged apparent (i.e. projected to the seafloor) fault rupture velocity of $2 \mathrm{~km} / \mathrm{s}$. The final tsunami source area was then determined with back-propagation lines using the modified tsunami travel times.

Back-propagation methods were also applied to the primary crests to discuss the location of major seafloor uplift in the tsunami source area. However, this was done only for the primary crests observed by OBPGs and GPS buoys, in order to limit data to near-field tsunami in deep sea, so that using data strongly affected by non-linear effects or dispersions was avoided as much as possible.

\section{Results \\ 4.1 Tsunami source area}

The tsunami source area of the 2011 off the Pacific coast of Tohoku Earthquake, determined by back-propagation of tsunami arrivals from offshore observation stations, is indicated in Fig. 2. The tsunami source area was approximately $500-\mathrm{km}$ long with a maximum width of about $200 \mathrm{~km}$. The eastern edge of the tsunami source area was along the west side of the Japan Trench, and the southern one was near $\mathrm{N} 36^{\circ}$. Meanwhile, the aftershock area (Hirose et al., 2011) includes the east side of the trench and the south of N36 ${ }^{\circ}$. Sea-level observed at TM1, TM2, GPS804, GPS802, GPS803, and GPS801 started to change almost instantly with the arrival of a seismic wave at each station. Therefore, we assumed that these offshore stations were within 

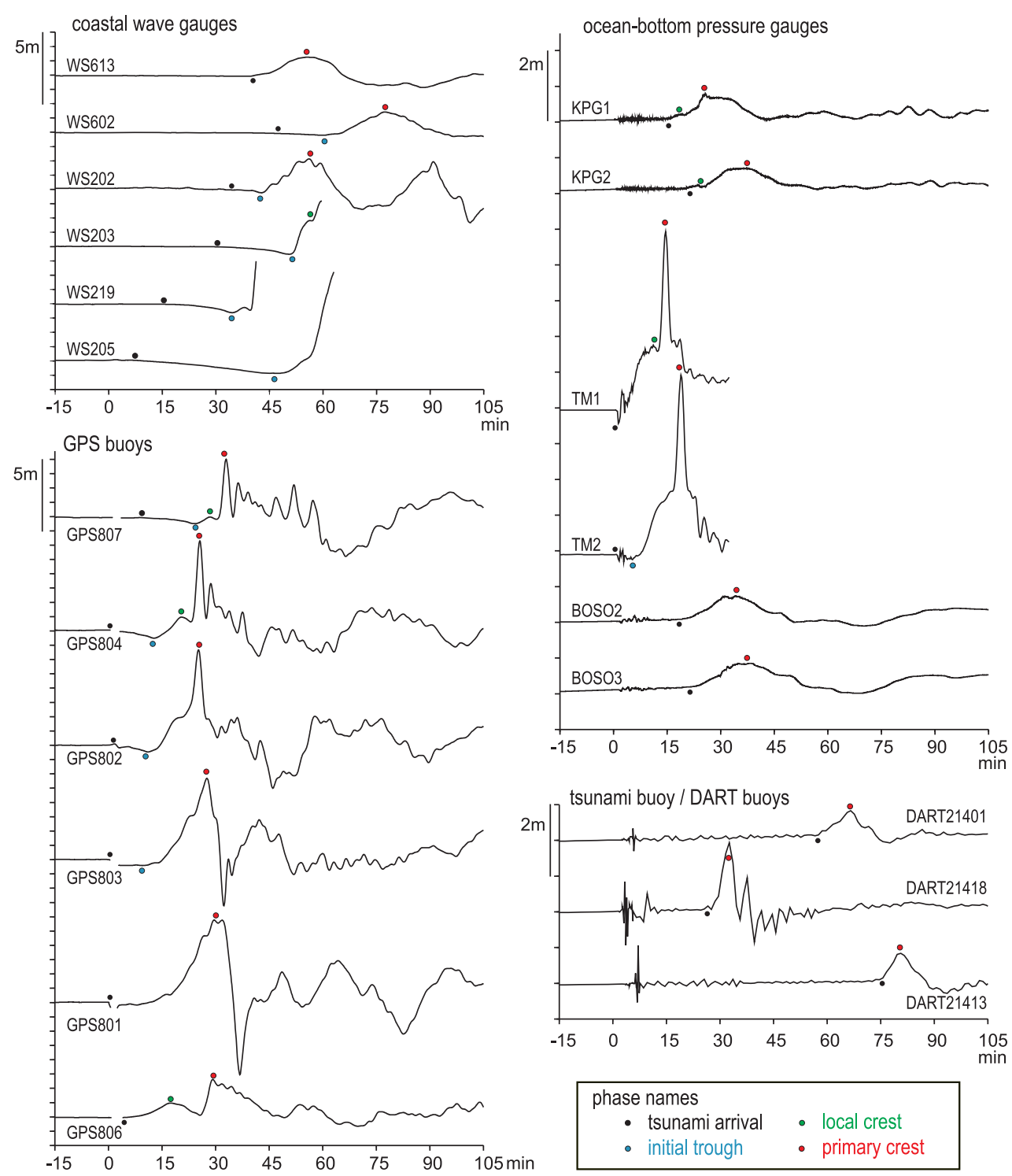

Fig. 1. Tsunami waveforms recorded offshore for the 2011 off the Pacific coast of Tohoku Earthquake and phase nomenclature used in this study. Data are low-pass filtered (see texts in Section 2). See Fig. 2 for locations of observation stations.

the tsunami source area.

\subsection{Back-propagation of the primary crest}

Back-propagation curves of the primary crests observed during the 2011 off the Pacific coast of Tohoku Earthquake tsunami are indicated in Fig. 3. All curves, except those from GPS807 and GPS806, go through the area near N38 E143.5 $5^{\circ}$ surrounded by the gray dotted line in Fig. 3. The area is several tens of kilometers east away from the epicenter.

\section{Discussion}

5.1 The accuracy of the estimated tsunami source area As shown in Fig. 1, the tsunami arrival times have some ambiguity. Especially, in the case where the direction of the initial deflection of the tsunami waveform is downwards, the ambiguity can be as much as several minutes. The northern limit of the tsunami source area shown in Fig. 2 is constrained only by the tsunami arrival time data (WS602, WS202, and WS203) whose initial deflections are down. Taking into consideration the water depth at this point (Fig. 2), we estimate that an error of $1 \mathrm{~min}$ in the arrival time can cause an error of up to $4 \mathrm{~km}$ in the location of the northern edge of the source area. On the other hand, because stations GPS804, GPS802, GPS803, and GPS801 are within the tsunami source area, the western limit of the tsunami source area must be west of these stations (as described in Section 4.1). However, the data available to us do not allow us to determine where the western limit of the source area lies between these GPS buoys stations and the Sanriku coastline. Accordingly, we believe that the maximum error in our estimation of the size of the tsunami source area is, at most, a few tens of kilometers for its northern and western limits.

\subsection{Possible highly-uplifted area in the tsunami source area}

If the seafloor uplift area identified was confined only within the small area through which most back-propagation curves of the primary crests go (Fig. 3 and Section 4.2), most of the arrival-time data of the primary crests observed at GPS buoys or OBPGs (Table 1) can be reasonably ex- 


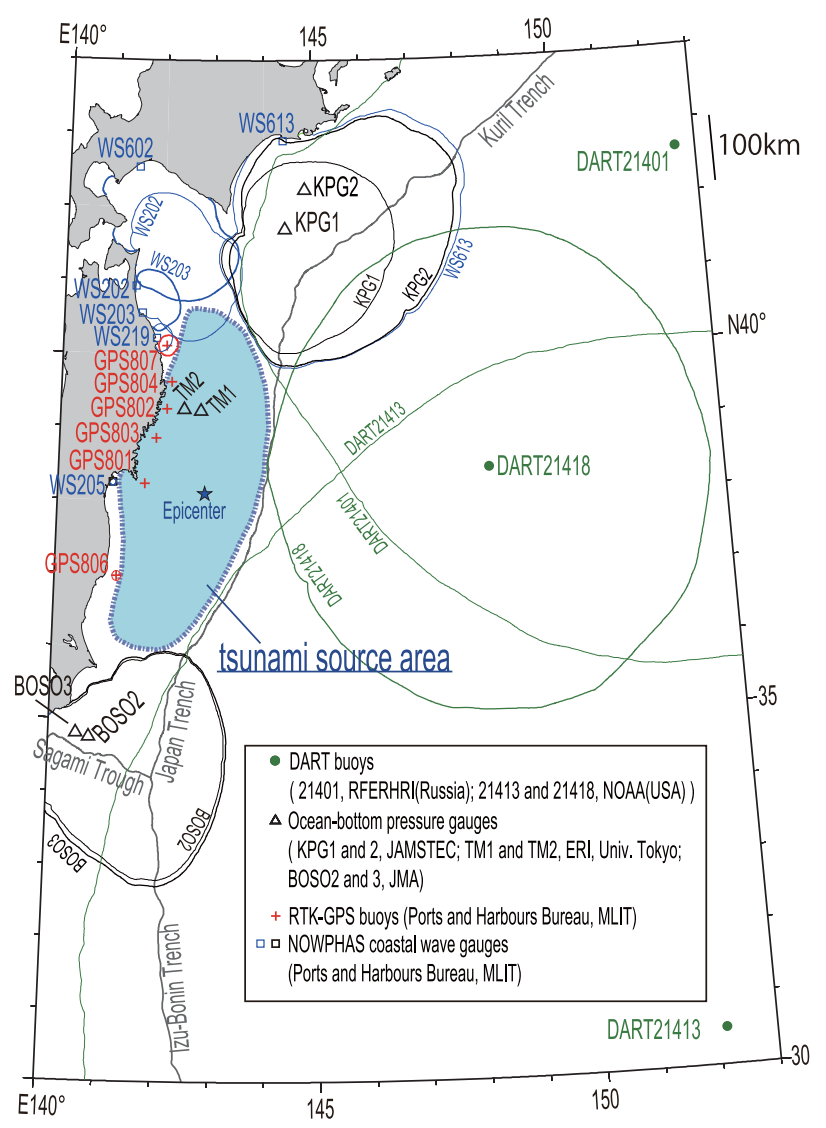

Fig. 2. Tsunami source area of the 2011 off the Pacific coast of Tohoku Earthquake determined by the back-propagation of tsunami arrivals from offshore observation stations.

plained; a highly-uplifted area in the tsunami source area is possibly located several tens of kilometers east of the epicenter. The area of large slip obtained from the inversion of seismic strong-motion waves (Yoshida et al., 2011) is almost coincident with the small area marked in Fig. 3. However, we suppose that this is but one of the possible solutions which can explain the timing of the primary crests.

One reason is, of course, that uplifted area from a great earthquake such as the 2011 off the Pacific coast of Tohoku Earthquake may be excited at multiple locations (e.g. more than one seafloor uplifted area) in the source area. In this case, it may be difficult to find the location of the maximum uplift area from the back-propagation curves of the primary crests from each station.

The other reason is that the back-propagation analysis is based on the assumption that the tsunami phase-velocity is equal to the square root of gravity multiplied by bathymetry. Nonlinearity of the phase velocity results in wave crests moving faster than this assumption; on the other hand, dispersion results in crests moving slower. Because these effects may cause some estimation errors in the highlyuplifted area, the results of this study do not allow us to discuss this in more detail.

The latter reason might be why it is difficult to explain the back-propagation curves from GPS807 and GPS806 (Fig. 3), unless the seafloor-uplift area has some extension in the north-to-south direction, instead of assuming the only seafloor uplift exists east of the epicenter.

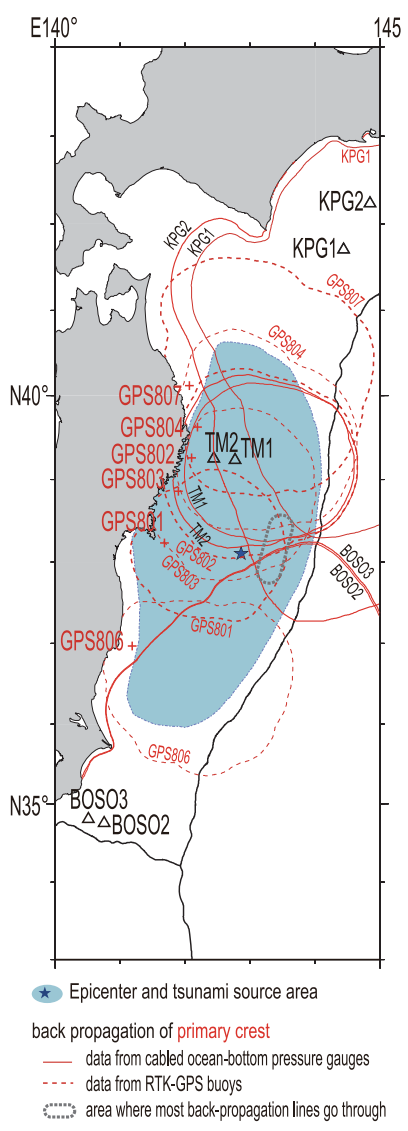

Fig. 3. Back-propagation of primary crests observed during the 2011 off the Pacific coast of Tohoku Earthquake tsunami.

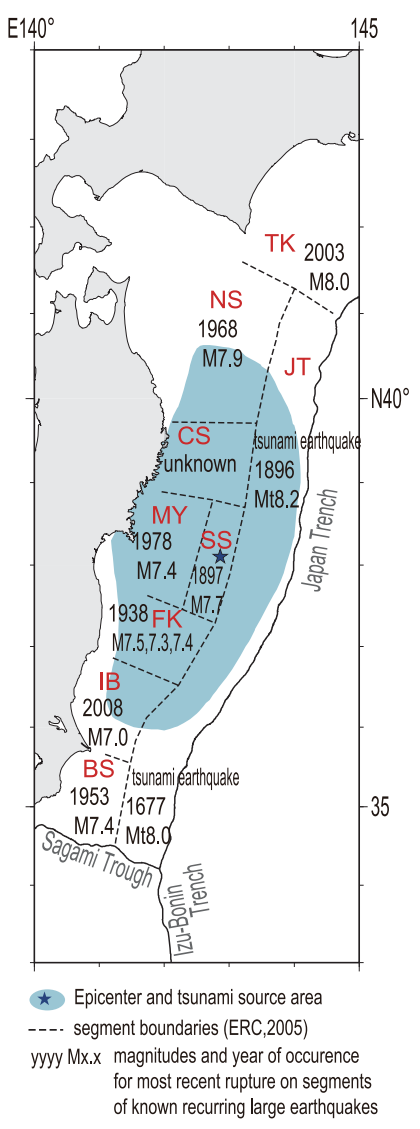

Fig. 4. Relationship of tsunami source areas determined in this study to known earthquake segments along the Japan Trench. 


\subsection{Segments of known recurring large earthquakes within the 2011 tsunami source area}

The tsunami source area, determined for the 2011 off the Pacific coast of Tohoku Earthquake, includes all or part of six segments of previous recurring large earthquakes (ERC, 2005) on the landward side of the Japan Trench (Fig. 4): the southern part of the off-northern-Sanriku (NS), the entire off-central-Sanriku (CS), the entire off-southern-Sanriku (SS), the entire off-Miyagi (MY), the entire off-Fukushima (FK), and the northern part of the off-Ibaraki (IB), segments. It also includes the central part of the off-Sanriku (northern) to off-Boso (southern) earthquake segment (JT), which lies seaward of the other segments and where previous tsunami earthquakes (e.g., the 1896 Meiji Sanriku tsunami earthquake of tsunami magnitude $\left(M_{\mathrm{t}}\right)$ 8.2) have occurred. However, our back-propagation calculations suggest that the main shock in 2011 did not rupture the northern part of the NS segment, the southernmost part of the IB segment, the entire BS segment, and the off-northern-Sanriku and off-Boso parts of the JT segment. The segments that were not ruptured during the 2011 off the Pacific coast of Tohoku Earthquake satisfy the conditions of the "first type" of seismic gap defined by Mogi (1979). We note that the off-Boso (southern) part of the JT segment, which has the potential to generate tsunami earthquakes once in every 400 years (ERC, 2005), has been inactive since the last tsunami earthquake event of 1677 . Thus, there is potential for another large tsunami earthquake to occur on this segment in the near future.

Acknowledgments. We appreciate the valuable comments of Professor Y. Tanioka and an anonymous reviewer. We used the Generic Mapping Tools software of Wessel and Smith (1998) to prepare our figures. Waveform data were acquired from MLIT (each coastal wave gauge and RTK-GPS buoy), JAMSTEC (stations KPG-1 and 2), ERI at the University of Tokyo (stations TM1 and 2), JMA (stations Boso-2 and 3), NOAA (DART 21413 and 21418), and RFERHR (DART 21401).

\section{References}

Amante, C. and B. W. Eakins, ETOPO1 1 arc-minute global relief model: Procedures, data source and analysis, NOAA Technical Memorandum, NESDIS NGDC-24, 19 p, 2009.

Earthquake Research Committee, the Headquarter of Earthquake Research Promotion, Report: 'National Seismic Hazard Maps for Japan (2005)'. http://www.jishin.go.jp/main/chousa/06mar_yosokue/NationalSeismicHazardMap s.pdf, 2005 (accessed on Apr. 1, 2011).

Fujisawa, I., S. Tateyama, and J. Fujisaki, Permanent ocean-bottom earthquake and tsunami observation system off the Boso Peninsula, Weath. Serv. Bull., 53, 127-166, 1986 (in Japanese).

González, F. I., E. N. Bernard, C. Meinig, M. C. Ebel, H. O. Mofjeld, and S. Stalin, The NTHMP tsunameter network, Nat. Hazards, 35, 25-39, doi:10.1007/s11069-004-2402-4, 2005.

Hirata, K., M. Aoyagi, H. Mikada, K. Kawaguchi, Y. Kaiho, R. Iwase, S. Morita, I. Fujisawa, H. Sugioka, K. Mitsuzawa, K. Suyehiro, H. Kinoshita, and N. Fujiwara, Real-time geophysical measurements on the deep seafloor using submarine cable in the southern Kurile subduction zone, IEEE J. Ocean Eng., 27, 170-181, 2002.

Hirose, F., K. Miyaoka, N. Hayashimoto, T. Yamazaki, and M. Nakamura, Outline of the 2011 off the Pacific coast of Tohoku Earthquake ( $M_{\mathrm{w}}$ 9.0)-Seismicity: foreshocks, mainshock, aftershocks, and induced activity—, Earth Planets Space, 63, this issue, 513-518, 2011.

Kato, T., Y. Terada, K. Ito, R. Hattori, T. Abe, T. Miyake, S. Koshimura, and T. Nagai, Tsunami due to the 2004 September 5th off the Kii Peninsula earthquake, Japan, recorded by a new GPS buoy, Earth Planets Space, 57, 279-301, 2005.

Mogi, K., Two kinds of seismic gaps, Pure Appl. Geophys., 117, 11721186, 1979.

Nagai, T., Development and improvement of the Japanese coastal wave observation network (NOWPHAS), J. Jpn. Soc. Civil. Eng., no. 609 (VI41), 1-14, 1998 (in Japanese).

Nagai, T., S. Satomi, Y. Terada, T. Kato, K. Nukada, and M. Kudaka, GPS buoy and 4 seabed installed wave gauge application to offshore tsunami observation, Proceedings of the 15th International Offshore and Polar Engineering Conference, Volume III, 292-299, 2005.

Seno, T. and K. Hirata, Did the 2004 Sumatra-Andaman earthquake involve a component of tsunami earthquakes?, Bull. Seismol. Soc. Am., 97, S296-S306, 2007.

Yoshida, Y., H. Ueno, D. Muto, and S. Aoki, Source process of the 2011 off the Pacific coast of Tohoku Earthquake with the combination of teleseismic and strong motion data, Earth Planets Space, 63, this issue, 565-569, 2011.

Wessel, P. and W. H. F. Smith, New improved version of Generic Mapping Tools released, Eos Trans. AGU, 79, 579, 1998.

Y. Hayashi (e-mail: yhayashi@mri-jma.go.jp), H. Tsushima, K. Hirata, K. Kimura, and K. Maeda 